\title{
PRODUCTION, OPTIMIZATION AND DEINKING CAPACITY OF ALKALINE CELLULASE PRODUCED FROM MUCOR CIRCINELLOIDES WSSDBS2F1
}

\author{
YAKUBU ABDULHADI ${ }^{*, * *}$ and VYAS ASHISH* \\ *Department of Microbiology, School of Bioscience and Bioengineering, \\ Lovely Professional University Phagwara, 144111 Punjab, India \\ ** Department of Science Laboratory Technology, Jigawa State Polytechnic Dutse, \\ PMB 7030, Jigawa State, Nigeria \\ \Corresponding author:V.Ashish, ashish.vyas@lpu.co.in
}

Received February 25, 2021

\begin{abstract}
An alkaliphilic Mucor circinelloides WSSDBS2F1 strain, with the ability to produce endoglucanase and exoglucanase enzymes, was isolated from decomposing bagasse, originating from a sugar processing mill in Punjab, India, and then screened. A pH range of 7-11, temperature of 30-60 ${ }^{\circ} \mathrm{C}$, incubation period of 4-12 days, different lignocellulosic waste and nitrogen sources were investigated for optimum production of cellulase enzyme. Response Surface Methodology (RSM) was the statistical tool used for optimization of endoglucanase and exoglucanase production, following the onefactor-at-a-time approach. The optimized endoglucanase was further evaluated for its ability to deink waste paper, compared to chemical deinking. It was found that the enzymatically deinked pulp had high ISO brightness, tensile, burst and tearing strength, as compared to chemically deinked and control pulps. Scanning electron microscopy and Fourier transform infrared spectroscopy (FTIR) were also used to confirm the action of the endoglucanase enzyme on waste paper.
\end{abstract}

Keywords: endoglucanase, exoglucanase, deinking, deinking, enzyme

\section{INTRODUCTION}

Alkaliphilic microorganisms, or alkaliphiles, are organisms that grow best at $\mathrm{pH}$ values exceeding $\mathrm{pH} 9$, usually in the 10-13 range of $\mathrm{pH}$. These include obligate alkaliphiles, which can grow only at $\mathrm{pH}$ values between $\mathrm{pH} 9$ and above, and facultative alkaliphiles, which grow optimally under high alkaline conditions, but can also grow near neutral $\mathrm{pH}$. Alkaliphilic microorganisms are an important source of useful, stable enzymes, among which are included cellulases, hemicellulases, xylanase, esterase, pectinase and amylase. ${ }^{1-5}$ They have a wide range of ecological niches, ranging from alkaline soda lakes ${ }^{6}$ and soils. $^{7,8}$ Cellulase is a family of three groups of enzymes called endo-(1,4)- $\beta$-D-glucanase (EC3.2.1.4), exo-(1,4)- $\beta$-D-glucanase (EC 3.2.1.91), and $\beta$-glucosidases (EC 3.2.1.21). The endoglucanase (EG) randomly attacks the internal $\mathrm{O}$-glycosidic bonds, resulting in glucan chains of different lengths; exoglucanase $(\mathrm{CBH})$, on the other hand, acts on the ends of the cellulose chain and releases $\beta$-cellobiose as the end product; while the $\beta$-glycosidases act specifically on the $\beta$ cellobiose disaccharides and produce glucose.

Industrial utilization of waste paper in the production of new one is increasing globally. Currently, the pulp and paper industry is one of the largest consumers of wood. Based on the demand for pulp and paper, due to global economic growth, more and more trees will be harvested, increasing the environmental burden. On the other hand, in paper recycling, chemical agents, such as sodium hydroxide, hydrogen peroxide, sodium carbonate, diethylene triamine pentacetic acid, sodium silicate and surfactants, are used in a large quantity by paper industries as conventional methods of deinking waste paper, which lead to expensive wastewater treatments to meet environmental regulations. ${ }^{10}$ Enzymes, such as lipase, xylanase, pectinase, cellulase, hemicellulase, amylase and esterase, are used as a substitute to chemical conventional methods of deinking waste papers. These enzymes are reported to be environmentally friendly, as compared to conventional deinking methods. It 
was established several decades ago that microbial enzymes might be useful in the processing of paper, since it is composed of natural polymers, such as cellulose, hemicelluloses and lignin. However, microbial enzymes started to be commercially used in the pulp and paper industry only in the previous decade, while at present microorganisms are used in other industrial processing steps as well. During the last decade, there has been a rapid increase in the number of possible applications of enzymes in pulp and paper industries. These include xylanase for enzymatic bleaching, lipase for pitch removal, as well as cellulase and hemicellulase for freshness enhancement. ${ }^{11}$

In the last few decades, many studies reported on the production of microbial cellulase enzymes and bioconversion of cellulose, especially for paper industries. Presently, the fermentation conditions and the costs of enzyme production are two major factors to be considered in the enzyme based bioconversion technology. Most of previous research works usually reported on the application of commercial cellulase enzymes for deinking purposes, yielding a considerable improvement, as compared to a conventional deinking method. ${ }^{12,13}$ The production of cellulase enzyme through fungi was also reported mostly within the range of acidic to neutral $\mathrm{pH}$, which is favourable for fungal growth. ${ }^{14-16}$ Although a few research attempts have been made on alkaline fungal cellulase, ${ }^{7,17-19}$ none is known to have been reported in the Punjab region, India, despite the availability of abundant lignocellulosic wastes. Thus, this paper aimed at isolating, screening and identifying a cellulase producing fungi in an alkaline environment from some alkaline related industrial effluents from Punjab, India, and its application in biodeinking waste papers.

\section{EXPERIMENTAL}

\section{Chemicals}

Chemicals and reagents used in this research were of analytical grade (AR) and were purchased from $\mathrm{Hi}$ Media (India) and Sigma (USA), unless otherwise stated.

\section{Isolation, screening and identification}

Alkaliphilic Mucor circinelloides WSSDBS2F1 was isolated and screened in our laboratory from decomposing bagasse received from Wahid Sandhar Sugars Ltd. Phagwara, Punjab, India. Based on the method of Vega, ${ }^{10}$ the fungus was kept in potato dextrose agar (PDA) and stored in a refrigerator at 4 ${ }^{\circ} \mathrm{C}$. Serial dilutions of the experimental soil samples with sterile distilled water were used for fungal isolation on Mandel and Reese screening medium, with the following composition $(\mathrm{g} / \mathrm{L})$ : proteose peptone 1.0, ammonium sulphate $\left(\mathrm{NH}_{4} \mathrm{SO}_{4}\right) \quad 1.4$, potassium dihydrogen phosphate $\mathrm{KH}_{2} \mathrm{PO}_{4}$ 2.0, urea $\mathrm{NH}_{2}-\mathrm{CO}-\mathrm{NH}_{2}$ 0.3, magnesium sulphate $\mathrm{MgSO}_{4} \cdot 7 \mathrm{H}_{2} \mathrm{O}$ 0.3 , calcium chloride $\mathrm{CaCl}_{2} 0.002$, ferrous sulphate $\mathrm{FeSO}_{4} .7 \mathrm{H}_{2} \mathrm{O} 0.005$, manganese sulphate $\mathrm{MnSO}_{4} \cdot \mathrm{H}_{2} \mathrm{O}$ 0.001 , zinc chloride $\mathrm{ZnCl}_{2}$ 0.017, carboxymethyl cellulose (CMC) 10 and cellulose powder (CP). It was then screened for the ability to produce cellulase using Mandel and Reese media. The broth media contained the following $(\mathrm{g} / \mathrm{L})$ : proteose peptone 1.0, ammonium sulphate $\left(\mathrm{NH}_{4} \mathrm{SO}_{4}\right)$ 1.4, potassium dihydrogen phosphate $\mathrm{KH}_{2} \mathrm{PO}_{4} \quad 2.0$, urea $\mathrm{NH}_{2}-\mathrm{CO}-\mathrm{NH}_{2} \quad 0.3$, magnesium sulphate $\mathrm{MgSO}_{4} \cdot 7 \mathrm{H}_{2} \mathrm{O} \quad 0.3$, calcium chloride $\mathrm{CaCl}_{2}$ 0.002, ferrous sulphate $\mathrm{FeSO}_{4} \cdot 7 \mathrm{H}_{2} \mathrm{O}$ 0.005 , manganese sulphate $\mathrm{MnSO}_{4} \cdot \mathrm{H}_{2} \mathrm{O} \quad 0.001$, zinc chloride $\mathrm{ZnCl}_{2}$ 0.017, carboxymethyl cellulose (CMC) 10 and cellulose powder (CP). The $\mathrm{pH}$ of the medium was adjusted to different alkaline levels using $\mathrm{NaOH}$ and $\mathrm{HCl}$.

\section{Phylogenetic analysis for identification}

The 18S rRNA gene sequence was identified using BLAST, with the 'nr' database of NCBI GenBank. Based on the maximum identity score, the first ten sequences were selected and aligned using Clustal W multiple alignment software program. The distance matrix was generated using the RDP database and the phylogenetic tree was constructed using MEGA X. ${ }^{8}$

\section{Enzyme assay}

The alkaline endoglucanase and exoglucanase were measured using the dinitrosalicyclic acid method of Miller. ${ }^{11}$ In this method, $0.5 \mathrm{~mL}$ of diluted enzyme in $0.05 \mathrm{M}$ citrate buffered ( $\mathrm{pH} 8.5$ ) was mixed with 0.5 $\mathrm{mL}$ of $1 \% \mathrm{CMC}$ for endoglucanase, and a Whatmann \#1 filter paper $(6 \times 1 \mathrm{~cm})$ was striped in the same buffer for exoglucanase. After incubation at $50{ }^{\circ} \mathrm{C}$ for $30 \mathrm{~min}$, the reaction was immediately stopped by the addition of $3 \mathrm{~mL}$ of dinitrosalicyclic acid, and by heating at $100{ }^{\circ} \mathrm{C}$ for $10 \mathrm{~min}$, followed by immediate cooling to stop the reaction. Absorbance was measured by a spectrophotometer at $540 \mathrm{~nm}$. One unit of CMC and filter paper were defined as the amount of enzyme produced by releasing $1 \mu$ mole of reducing sugar equivalent to glucose per minute under standard conditions.

\section{One-factor-at-a-time (OFAT) approach}

Important cellulase enzyme production parameters, such as nitrogen source, temperature, $\mathrm{pH}$ and incubation time, were optimized, while keeping the others constant. The effects of $\mathrm{pH}$ ( 7 to 11), temperature $\left(30\right.$ to $\left.60{ }^{\circ} \mathrm{C}\right)$, incubation time $(4,6,8,10$ and 12 days), lignocellulosic carbon source (rice straw, wheat straw and sugarcane bagasse) and nitrogen source $\left(\mathrm{HN}_{4} \mathrm{SO}_{4}, \mathrm{HN}_{4} \mathrm{HCO}_{3}, \mathrm{HN}_{4} \mathrm{Cl}\right.$ and $\left(\mathrm{NaNO}_{3}\right)$ 
were examined. All the experiments involving these parameters were carried out in triplicate, with mean standard deviation. $^{12}$

Optimization of cellulase production by the statistical approach

Design Expert was the statistical software tool used during tabulation and processing process that allows a quick and simple data appraisal. Combined physical and nutritional factors were optimized by response surface methodology using the central composite design (CCD). Three major factors were selected: $\mathrm{pH}$, temperature and $\mathrm{HN}_{4} \mathrm{SO}_{4}$ (Table 1). A total of 20 different experiments, randomly selected by the software, were conducted. All experiments were carried out in triplicate and the mean enzyme production was used as the variable responses $Y$. Equation (1) indicates the second-order model used in describing the relationship between the independent variable and the response. The final RSM predicted response was further validated experimentally. ${ }^{6,13}$

$\mathrm{Y}=0+1 \mathrm{~A}+2 \mathrm{~B}+3 \mathrm{C}+11 \mathrm{~A} 2+22 \mathrm{~B} 2+33 \mathrm{C} 2+$ $12 \mathrm{AB}+13 \mathrm{AC}+23 \mathrm{BC}$

where $Y$ is the predicted response parameter, $\beta_{0}, \beta_{1}, \beta_{3}$, $\beta_{11}, \beta_{22}, \beta_{33}, \beta_{12}, \beta_{13}$ and $\beta_{23}$ are constant regression coefficients of the model, $\beta_{0}$ is the intercept term, $\beta_{1}, \beta_{2}$ and $\beta_{3}$ are linear coefficients, $\beta_{11}, \beta_{22}$ and $\beta_{33}$ are squared coefficients, $\beta_{12}, \beta_{13}$ and $\beta_{23}$ are interaction coefficients and $\mathrm{A}, \mathrm{B}, \mathrm{C}, \mathrm{A}^{2}, \mathrm{~B}^{2}, \mathrm{C}^{2}, \mathrm{AB}, \mathrm{AC}$ and $\mathrm{BC}$ are independent parameters.

\section{Evaluation of endoglucanase enzyme deinking potential}

The resultant oven-dried pulp was suspended in 50 $\mathrm{mM}$ sodium citrate buffer, and enzymatic treatment was conducted using an enzyme dose of CMCase of 50 $\mathrm{mL} / 10 \mathrm{~g}$ of oven-dried pulp at $50{ }^{\circ} \mathrm{C}$. To inactivate the enzyme, the pulp suspension was boiled for $10 \mathrm{~min}$. A

Table 1

Levels of independent variables and experimental range from CCD for optimization of CMCase and FPase

\begin{tabular}{llcccc}
\hline \multirow{2}{*}{ Variable } & \multirow{2}{*}{ Factor } & \multirow{2}{*}{ Range } & \multicolumn{3}{c}{ Level of experimental variables } \\
\cline { 5 - 6 } & & & Low $(-1)$ & Medium $(0)$ & High $(+1)$ \\
\hline $\mathrm{A}$ & $\mathrm{pH}$ & $7-11$ & 7 & 8.5 & 11 \\
$\mathrm{~B}$ & Temperature $\left({ }^{\circ} \mathrm{C}\right)$ & $30-60$ & 30 & 45 & 60 \\
$\mathrm{C}$ & Ammonium Sulphate $(\%)$ & $1-5$ & 1 & 3 & 5 \\
\hline
\end{tabular}

\section{RESULTS AND DISCUSSION}

\section{Isolation, screening and enzymatic assay}

In the present investigation, cellulose degrading alkaliphilic fungi were isolated from industrial effluents. A total of eight fungal cultures were isolated within the alkaline $\mathrm{pH}$ range of 7 to 11, using Mandel and Reese media supplemented with CMC and cellulose powder as a carbon source. The result clearly depicts that potential fungal cultures were found growing at control assay, without enzyme treatment, was also carried out under identical conditions. Finally, the pulp was washed with tap water through a 220-mesh wire and subjected to flotation for $20 \mathrm{~min}$ in the presence of $0.1 \%$ Tween 80 as surfactant and $0.1 \% \mathrm{CaCl}_{2}$ as a flotation aid. The flotation device was constructed in our laboratory as per the method of Pala et al. ${ }^{14}$ with modifications. An A4 paper was printed with approximately 640 words, using a Xerox printer, and was used as waste paper. The optimized endoglucanase was later evaluated for its deinking capability, compared with chemical deinking and a control. The chemicals used to replace the enzyme were: $2 \%$ $\mathrm{Na}_{2} \mathrm{SiO}_{3}, 2 \% \mathrm{NaOH}$ and $1 \% \mathrm{H}_{2} \mathrm{O}_{2}$. After enzymatic, chemical and control deinking processes, as well as flotation, the resultant pulps were prepared according to the corresponding TAPPI standard and sent to the Central Pulp and Paper Research Institute (CPPRI), Saharanpur, 247001 (U.P.) India, for testing pulp brightness, tensile strength, bursting strength and tearing strength. Morphological and structural changes of deinked and control pulp samples were observed using a scanning electron microscope (SEM). Attenuated total reflectance-Fourier transform infrared spectroscopy (ATR-FTIR) was used to study the surface functional groups of handsheets prepared from the enzymatically and chemically deinked pulp samples, as well as the control, using an attenuated total reflectance (ATR) measuring cell.

\section{Statistical analysis}

The statistical tool used in the research was the analysis of variance (ANOVA), using data generated from central composite design (CCD) experiments for CMCase and FPase production. Values of $\mathrm{p}<0.05$ were considered statistically significant. 
The observation of the clear zone of hydrolysis on the Petri plates is an indication of the presence of potential alkaline cellulase enzyme. ${ }^{20-22}$ Fungi that produce a clear zone are considered as potential cellulase enzyme producers. However, halos around isolates on solid media may sometimes be due to the presence of membrane bound hydrolysis, which causes the formation of clearing when the substrates are hydrolyzed. ${ }^{23}$ Based on this reason, alkaline cellulase enzymes were produced using submerged fermentation techniques. The endoglucanase and exoglucanase activities at alkaline $\mathrm{pH}$ on this fungal culture were assessed with CMCase $(2.78 \mathrm{IU} / \mathrm{mL})$ and FPase (3.18 FPU $/ \mathrm{mL})$, respectively, after incubation of 8 days at $30^{\circ} \mathrm{C}$ and $\mathrm{pH} 8$.

\section{Identification}

Based on colony appearance on Mandel and Reese medium, as well as on potato dextrose agar medium (PDA), the fungal isolate WSSDBS2F1 is a fast-growing fungus, with white coloured colony covering the whole plate and the same reverse pigmentation (Fig. 1a). Based on microscopic examination, the fungus has broad hyphae, which are non-septate, with long sporangiospores that terminate in a round spore filled sporangia (Fig. 1b). 18S rRNA gene identification by PCR was also conducted. Integrated Transcribed Spacer (ITS1 5'GTAGTCATATGCTTGTCTC-3') and (ITS4 5'CTTCCGTCAATTCCTTTAAG-3') primers were amplified by the $18 \mathrm{~S}$ rRNA gene region, sequenced and analyzed for similarity among species in the NCBI database. A BLAST search revealed the culture has $96.84 \%$ similarity with Mucor circinilloides (GenBank accession number HQ845293.1) and thus has been assigned as Mucor circinilloides WSSDBS2F1.

The neighbor-joining tree, depicting the phylogenetic relationship of the isolate with related species, was achieved after muscle aligning with MEGA X software (Fig. 2). A similar fungus marked as S3 was isolated from mining tailing in Anshan for $\mathrm{Pb}$ bioremediation. The internal transcribed spacer (ITS) sequencing revealed that the isolate belongs to Mucor circinelloides. Another fungal isolate Q531 was identified when 18S rDNA sequence was conducted and submitted to Genbank with the accession number KU523400. The BLAST search results revealed the sequence has $99 \%$ similarity with $M$. circinelloides. ${ }^{24}$

Optimization of culture conditions by the onefactor-at-a-time (OFAT) approach Effect of initial $p H$

An essential physical factor influencing microbial growth and metabolism is the $\mathrm{pH} .{ }^{25} \mathrm{It}$ is one of the most important physical parameters, its increase or decrease may affect microbial growth and enzyme production. ${ }^{26}$ The effect of $\mathrm{pH}$ on fungal growth and cellulase enzyme production was studied in the range of 7 to 11 . It was observed that enzyme activity decreases with an increase in the $\mathrm{pH}$ value. In the case of $M$. circinelloides WSSDBS2F1, both CMCase and FPase were found to have the highest activity at $\mathrm{pH} 7(2.78 \mathrm{IU} / \mathrm{mL}$ and $3.33 \mathrm{FPU} / \mathrm{mL})$ and the lowest - at $\mathrm{pH} 11$ - was found only for FPase (0.19 FPU/mL), while no activity was found in CMCase at pH 11 (Fig. 3a).

Similarly, M. circinelloides NRRL 26519 was reported to be fairly and highly active in the production of endoglucanase over a wider range of $\mathrm{pH}$ 3.5-7.5 by Saha (2004). ${ }^{27}$ Our results revealed that $M$. circinelloides WSSDBS2F1 is active at alkaline $\mathrm{pH}$. Similar findings for different fungal strains in alkaline environment have been reported by Vega et al., ${ }^{7}$ Prasad et al., ${ }^{17}$ Muhammad et al. ${ }^{18}$ and Dutta et al. ${ }^{19}$

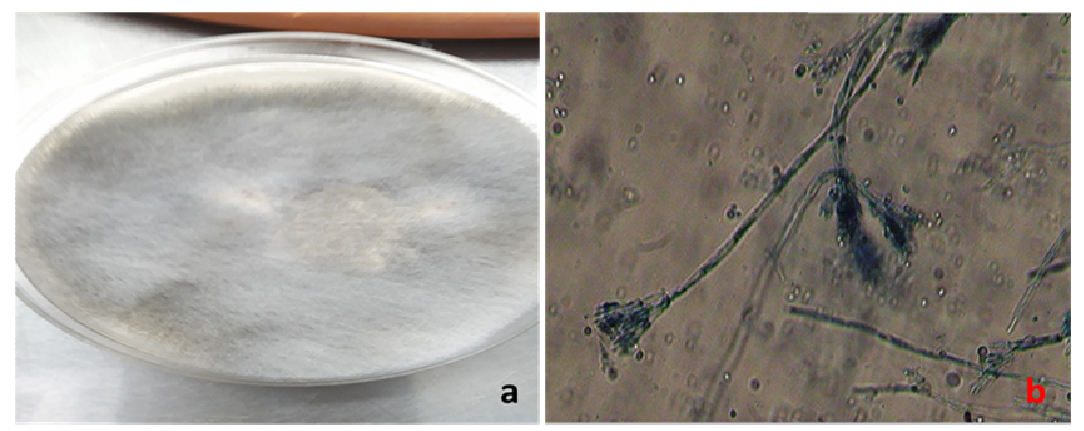

Figure 1: Visual appearance (a) and microscopic view (b) of Mucor circinelloides WSSDBS2F1 


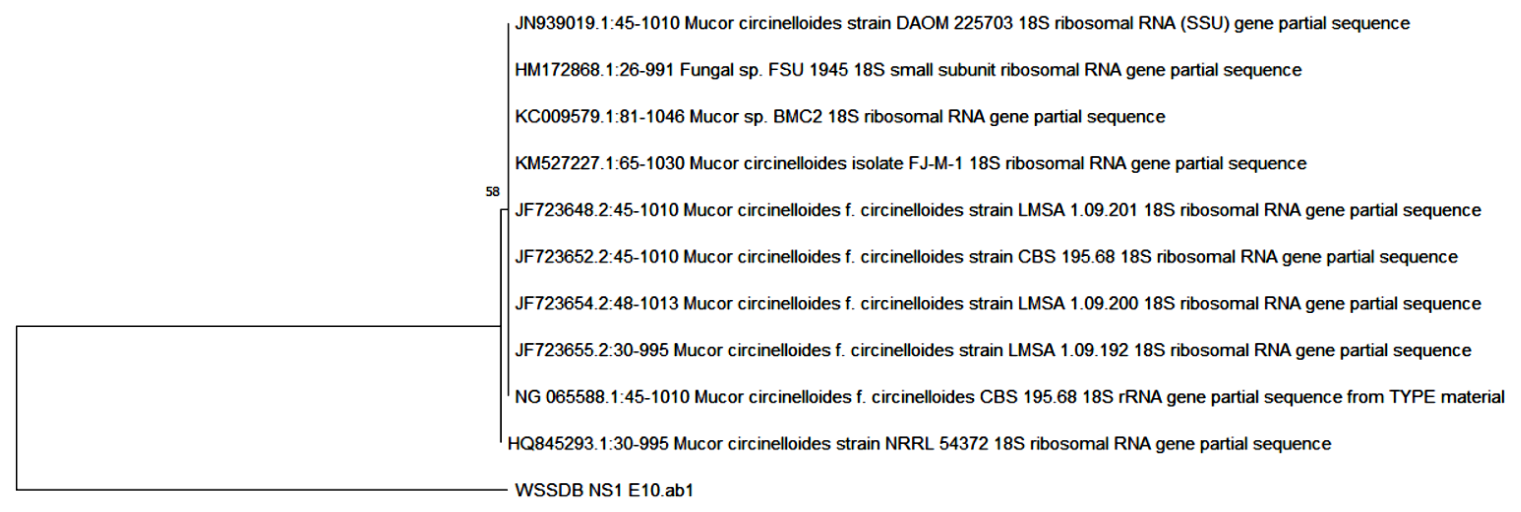

กตก

Figure 2: Phylogenic tree based on ITS region gene sequences showing relationship between fungal strain WSSDBS2F1 and the closest species of Mucor circinelloides based on the neighbor-joining analysis
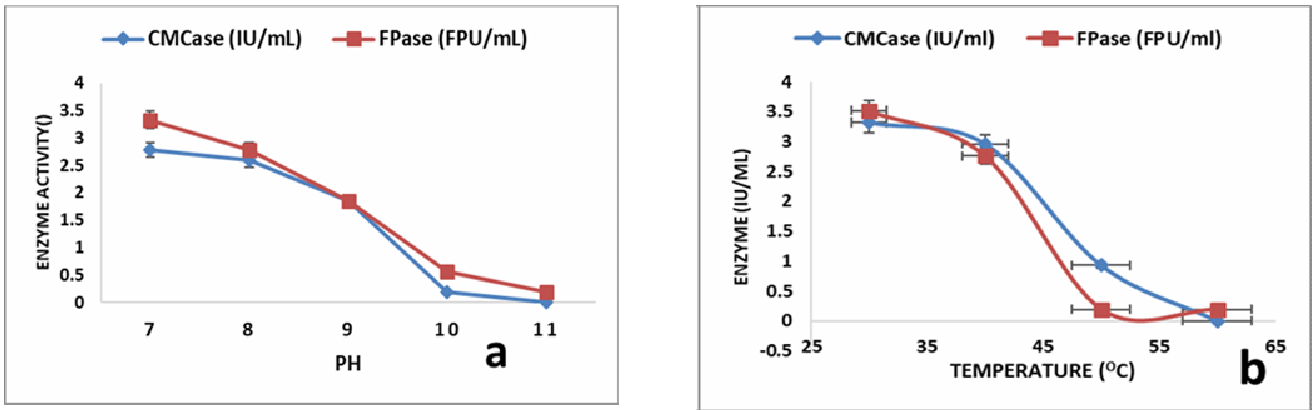

Figure 3: Effect of (a) initial $\mathrm{pH}$ and (b) temperature on the production of endoglucanase and exoglucanase

\section{Effect of temperature}

Another essential physical factor affecting the survival and growth of microorganisms is temperature. Any specific enzyme-mediated degradation process will have an optimum temperature. ${ }^{25}$ The temperature for fungal growth and alkaline cellulase production was measured in the ranges of $30{ }^{\circ} \mathrm{C}$ to $60{ }^{\circ} \mathrm{C}$, as shown in Figure 3b. The optimum CMCase and FPase activity of alkaline $M$. circinelloides WSSDBS2F1, based on the increase in temperature, was recorded at $30{ }^{\circ} \mathrm{C}$ (3.32 IU/mL and 3.52 FPU/mL) and the lowest at $60{ }^{\circ} \mathrm{C} \quad(0.00 \mathrm{IU} / \mathrm{mL}$ and $0.19 \mathrm{FPU} / \mathrm{mL})$, respectively. This result is in agreement with those of Jahangeer et al. (2005), who reported optimum cellulase enzyme production at $30{ }^{\circ} \mathrm{C}$ from Aspergillus niger. Ravindran et al. ${ }^{29}$ also reported optimum CMCase from Chaetomium sp. at $50{ }^{\circ} \mathrm{C}$, at different alkaline $\mathrm{pH}$, using agricultural and industrial wastes as substrates.

\section{Effect of different natural lignocellulosic carbon sources}

Three different types of agricultural wastes were selected for evaluating the production of extracellular alkaline cellulase on alkali pretreated $(\mathrm{NaOH}) \quad$ lignocellulolytic substrates. Lignocellulolytic substrates, viz. rice straw (RS), wheat straw (WS) and sugarcane bagasse (SB), were selected. These agro-lignocellulosic wastes were used to substitute carboxymethyl cellulose (CMC) and cellulose powder as sole sources of carbon in the fermentation media. The optimum conditions of the fermentation were maintained at $\mathrm{pH} 8$, temperature $30{ }^{\circ} \mathrm{C}$ and 8 days incubation period for the evaluation of both enzymes. Optimum CMCase (3.70 IU/mL) and FPase (3.89 FPU/mL) activities were shown on sugarcane bagasse, while for wheat straw the lowest ones were recorded $(2.04 \mathrm{IU} / \mathrm{mL}$ and $2.22 \mathrm{FPU} / \mathrm{mL})$ for CMCase and FPase, respectively (Fig. 4a). 
These findings were in accordance with the work of Sasi et al.,${ }^{30}$ in which maximum CMCase of $0.128 \mathrm{~g} / \mathrm{mL}$ was found in rice bran, followed by wheat bran $(0.097 \mathrm{~g} / \mathrm{mL})$ and sugarcane bagasse (0.019), respectively. Bhavsar et al..$^{31}$ also reported maximum CMCase production of 7.4 IU/mL from banana stem, followed by rice straw $-5.4 \mathrm{IU} / \mathrm{mL}$ using fungal cellulase.

\section{Effect of nitrogen source}

Four different inorganic nitrogen sources, including ammonium sulphate $\left(\mathrm{HN}_{4} \mathrm{SO}_{4}\right)$, ammonium carbonate $\left(\mathrm{HN}_{4} \mathrm{HCO}_{3}\right)$, ammonium chloride $\left(\mathrm{HN}_{4} \mathrm{Cl}\right)$ and sodium nitrate $\left(\mathrm{NaNO}_{3}\right)$, were investigated (Fig. 4b). The results showed that optimum CMCase $(3.52 \mathrm{IU} / \mathrm{mL})$ and FPase activity (3.50 FPU/mL) was found on $\mathrm{HN}_{4} \mathrm{SO}_{4}$ and minimum - on $\mathrm{NaNO}_{3}(1.11 \mathrm{IU} / \mathrm{mL}$ and 1.11 FPU/mL), respectively. These results are in agreement with those reported by Sasi et al., ${ }^{30}$ who found that ammonium sulphate increases the amount of cellulase produced from Aspergillus flavus, as well as by Vyas, ${ }^{32}$ who found optimum cellulase production when ammonium sulphate was used as a nitrogen source.

\section{Effect of incubation time}

The production of cellulase enzyme was determined as a function of the incubation period (4, 6, 8, 10 and 12 days). Following incubation, it was observed that initially an increase in the incubation period increased enzyme activity, which then declined after reaching a peak on the $8^{\text {th }}$ day of incubation. As indicated in Figure 5 (a), optimum CMCase and FPase activities, of 2.78 $\mathrm{IU} / \mathrm{mL}$ and $3.88 \mathrm{FPU} / \mathrm{mL}$, respectively, were recorded on the $8^{\text {th }}$ day of incubation, while the lowest activity was found on the $12^{\text {th }}$ day - of $0.37 \mathrm{IU} / \mathrm{mL}$ and $0.49 \mathrm{FPU} / \mathrm{mL}$, respectively.

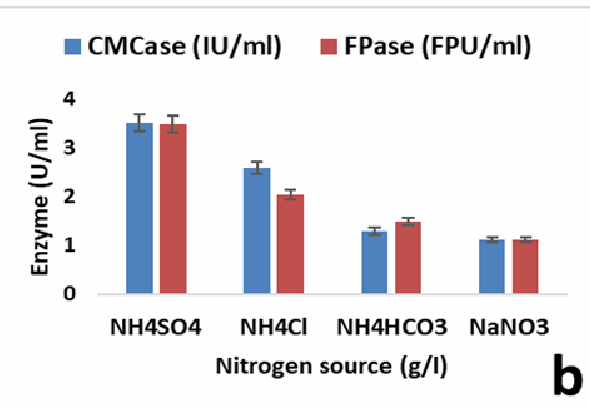

Figure 4: Effect of (a) different carbon and (b) nitrogen sources on the production of endoglucanase and exoglucanase (error bars represent mean \pm standard deviation)
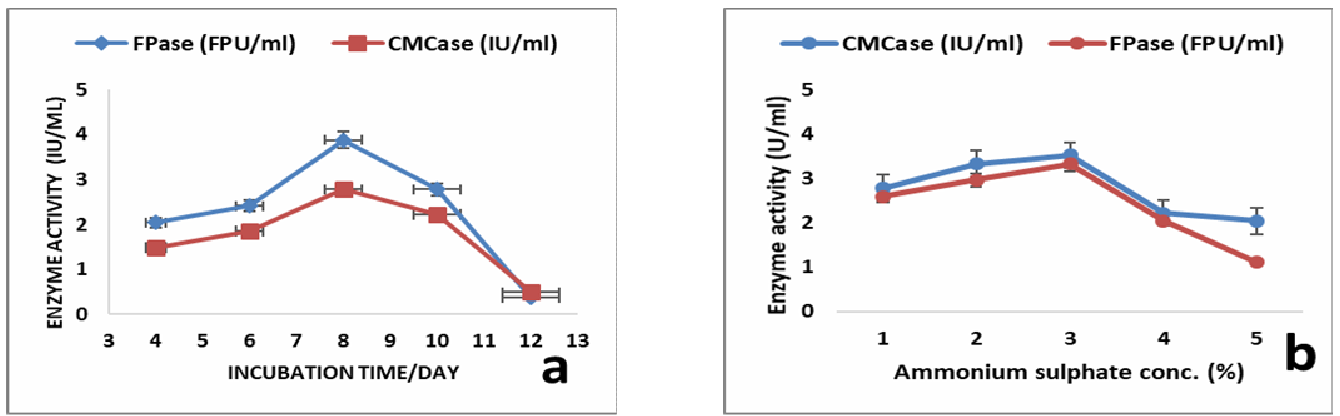

Figure 5: Effect of (a) incubation time and (b) $\mathrm{NH}_{4} \mathrm{SO}_{4}$ concentration on the production of endoglucanase and exoglucanase (error bars represent mean \pm standard deviation)

This result is in agreement with the work of Ramanathan, ${ }^{33}$ where maximum CMCase $(1.92 \pm 0.005)$ and FPase $(1.34 \pm 0.003)$ were produced from Fusarium oxysporum after eight days of incubation. However, maximum production at a low incubation time was reported by El-hadi, ${ }^{34}$ who found maximum enzymatic activity after $9 \mathrm{~h}$ of incubation time, for the production of CMCase from Aspergillus hortai. 


\section{Effect of ammonium sulphate concentration}

The effect of various ammonium sulphate concentrations on alkaline cellulase production was investigated, following its optimum among the different nitrogen sources examined previously. Optimum CMCase and FPase activities $(3.52 \mathrm{IU} / \mathrm{mL}$ and $3.33 \mathrm{FPU} / \mathrm{mL}$ ) were found after the addition of $3 \%$ ammonium sulphate (Fig. 5b). The least activity was found when the ammonium sulphate concentration was increased to $5 \%$ (2.04 IU/mL and $1.11 \mathrm{FPU} / \mathrm{mL}$ ). An increase or decrease of the ammonium sulphate concentration from the optimum value will lower the rate of enzyme production. This result indicated that ammonium sulphate is one of the best nitrogen sources for alkaline cellulase production. This result is similar to the findings reported by Vyas ${ }^{32}$ and Sasi. ${ }^{30}$

\section{Central composite design (CCD) of experiment}

The three most important parameters, identified following enzyme production by the one-factor-at-a-time (OFAT) approach, were further optimized using the central composite design (CCD) by the response surface methodology (RSM). The predicted and actual responses from the central composite experimental plan, for both CMCase and FPase, were summarized in Table 2. ANOVA was used to estimate endo- and exoglucanase as a function of independent variables and provide a regression equation, where models precisions were normally determined by the coefficient $\left(R^{2}\right)$. Its values always range between 0 to 1 , where the order of magnitude suggests the goodness of the model. ${ }^{35}$ The $R^{2}$ values of CMCase and FPase enzymes are 0.9852 and 0.9899 , respectively. These $R^{2}$ values mean that $98.52 \%$ and $98.99 \%$ of the behavior can be interpreted for alkaline cellulase enzyme production, while only $1.48 \%$ and $1.01 \%$ full variance cannot be explained by the models. According to Yusuf et al. ${ }^{36}$ for high accuracy and goodness of the polynomial model, the $R^{2}$ value must be close to 1 . The adjusted $R^{2}$ from this model was 0.9721 and 0.9808 for CMCase and FPase, respectively. This has shown a good relationship between the actual and the predicted values. From the results obtained, the predicted $R^{2}$ values for CMCase (0.9388) and FPase (0.9279) agreed with adjusted $R^{2}$ values of 0.9798 , respectively. Hence, the model clarifies the relationship between the response and the independent variables.
Adequate precisions of the model measured the signal to noise ratio for CMCase and FPase (31.58 and 36.622), respectively, indicated an adequate signal, while the result showed that the model is significant. This result agreed with that of Sharma, ${ }^{37}$ with adequate precision values of 17.4 and 14.4, respectively, while optimizing nutrient supplements for the removal of $\mathrm{Cr}$ (VI) by Aspergillus lentulus AML05. The significance of the models is generally measured based on the $\mathrm{P}$-value of the corresponding $\mathrm{F}$ value (prob $>\mathrm{F}$ ). The higher the $\mathrm{F}$ value and corresponding lower prob $>\mathrm{F}$ value, the higher the importance of the corresponding coefficients $\left(R^{2}\right) .{ }^{38}$ In Table 3, the results exhibit high $F$ values for alkaline CMCase and FPase. Thus, $F$ values of 74.56 and 109.01, respectively, were recorded, with their corresponding prob $>\mathrm{F}$ values ( $\mathrm{P}$ value) of $<0.0001$, indicating that the model is significant. This means the probability the $\mathrm{F}$ value of the model could be due to noise was $0.01 \%$.

To ensure the importance of each coefficient, $\mathrm{P}$ values were adopted as tools. The prob $>\mathrm{F}<$ 0.05 values showed that the models were significant. This means that $\mathrm{A}, \mathrm{B}, \mathrm{C}, \mathrm{A}^{2}, \mathrm{~B}^{2}, \mathrm{C}^{2}$, $\mathrm{AB}, \mathrm{AC}$, as well as $\mathrm{BC}$, are the significant model terms. The lack-of-fit $\mathrm{F}$ values of the models for CMCase and FPase were 2.80 and 4.93, respectively, with their corresponding lack-of-fit $P$ value of 0.1414 and 0.0524 , respectively, indicating that the lack-of-fit was not significant and that the models are very accurate, without any noise (Tables 4 and 5). Borugadda and Goud ${ }^{35}$ reported that a lack-of-fit must be estimated to examine the analysis of variance (ANOVA) for each model coefficient and ensure an in-depth model fit. Manogaran et al. ${ }^{39}$ and Ibrahim et al. ${ }^{40}$ reported a non-significant lack-of-fit by describing it as an excellent fit. Based on the results obtained, there was a strong relationship between the actual and the predicted model values for both CMCase and FPase, as depicted in the equations below.

The 3D response surface in the central composite design (CCD) shows an interaction between two different factors, while keeping the other factors constant (Fig. 6). This visualization helps understand the interaction between two factors and pinpoint the optimum level of each parameter for a maximal response. ${ }^{41}$ 


\section{YAKUBU ABDULHADI and VYAS ASHISH}

Table 2

Experimental design with coded levels of variables used in central composite design (CCD) with experimental and predicted values for CMCase and FPase activities

\begin{tabular}{|c|c|c|c|c|c|c|c|c|}
\hline \multirow{2}{*}{$\begin{array}{c}\text { Standard } \\
\text { order }\end{array}$} & \multirow{2}{*}{ Run } & \multirow{2}{*}{$\begin{array}{c}\text { Factor } 1 \\
\mathrm{pH}\end{array}$} & \multirow{2}{*}{$\begin{array}{c}\text { Factor } 2 \\
\text { Temperature }\left({ }^{\circ} \mathrm{C}\right)\end{array}$} & \multirow{2}{*}{$\begin{array}{c}\text { Factor } 3 \\
\mathrm{NH}_{4} \mathrm{SO}_{4}(\%)\end{array}$} & \multicolumn{2}{|c|}{ CMCase (IU/mL) } & \multicolumn{2}{|c|}{ FPase (FPU/mL) } \\
\hline & & & & & Actual & Predicted & Actual & Predicted \\
\hline 1 & 4 & -1 & -1 & -1 & 3.33 & 3.41 & 3.64 & 3.64 \\
\hline 2 & 9 & 1 & -1 & -1 & 0.19 & 0.25 & 0.19 & 0.13 \\
\hline 3 & 6 & -1 & 1 & -1 & 0.37 & 0.33 & 0.56 & 0.52 \\
\hline 4 & 10 & 1 & 1 & -1 & 0.19 & 0.23 & 0.19 & 0.24 \\
\hline 5 & 13 & -1 & -1 & 1 & 4.26 & 4.30 & 4.26 & 4.27 \\
\hline 6 & 3 & 1 & -1 & 1 & 0.37 & 0.48 & 0.37 & 0.48 \\
\hline 7 & 11 & -1 & 1 & 1 & 0.74 & 0.76 & 0.56 & 0.68 \\
\hline 8 & 18 & 1 & 1 & 1 & 0.00 & $1.023 \mathrm{E}-003$ & 0.19 & 0.13 \\
\hline 9 & 15 & -1 & 0 & 0 & 2.03 & 1.94 & 2.41 & 2.20 \\
\hline 10 & 2 & 1 & 1 & -1 & 0.19 & -0.021 & 0.19 & 0.16 \\
\hline 11 & 17 & 0 & -1 & 0 & 2.41 & 2.13 & 2.22 & 2.04 \\
\hline 12 & 14 & 0 & 1 & 0 & 0.37 & 0.35 & 0.37 & 0.30 \\
\hline 13 & 16 & -1 & -1 & 1 & 0.37 & 0.24 & 0.37 & 0.30 \\
\hline 14 & 8 & 0 & 0 & 1 & 0.74 & 0.57 & 0.74 & 0.56 \\
\hline 15 & 7 & -1 & 0 & 0 & 0.56 & 0.69 & 0.56 & 0.76 \\
\hline 16 & 20 & 0 & 0 & 0 & 0.56 & 0.69 & 0.74 & 0.76 \\
\hline 17 & 12 & 0 & 0 & 0 & 0.37 & 0.69 & 0.74 & 0.76 \\
\hline 18 & 1 & 0 & 0 & 0 & 0.56 & 0.69 & 0.56 & 0.76 \\
\hline 19 & 19 & 0 & 0 & 0 & 0.74 & 0.69 & 0.74 & 0.76 \\
\hline 20 & 5 & 0 & 0 & 0 & 0.74 & 0.69 & 0.74 & 0.76 \\
\hline
\end{tabular}

Table 3

Summary of ANOVA for central composite design (CCD) optimization results for CMCase and FPase

\begin{tabular}{lccc}
\hline Parameters & CMCase & FPase & Remark \\
\hline F value & 74.56 & 109.01 & \\
Prob $>$ F & $<0.0001$ & $<0.0001$ & Significant \\
$R^{2}$ value & 0.9853 & 0.9899 & \\
Adjusted $R^{2}$ & 0.9721 & 0.9808 & \\
Predicted $R^{2}$ & 0.9388 & 0.9279 & \\
Adequate precision & 31.958 & 36.622 & Adequate signal to noise ratio \\
Lack-of-fit F value & 2.80 & 4.93 & Not significant \\
Lack-of-fit prob $>\mathrm{F}$ & 0.1414 & 0.0524 & \\
\hline
\end{tabular}


Table 4

Analysis of variance (ANOVA) surface quadratic model for endoglucanase (CMCase)

\begin{tabular}{lcccccc}
\hline Source & Sum of squares & DF & Mean square & $F$ value & Prob $>$ F value & Remark \\
\hline Model & 25.12 & 9 & 2.79 & 109.01 & $<0.0001$ & Significant \\
$\mathrm{A}=\mathrm{pH}$ & 10.36 & 1 & 10.36 & 404.68 & $<0.0001$ & - \\
$\mathrm{B}=$ temperature & 7.55 & 1 & 7.55 & 294.89 & $<0.0001$ & - \\
$\mathrm{C}=\mathrm{NH}_{4} \mathrm{SO}_{4}$ & 0.17 & 1 & 0.17 & 6.50 & 0.0289 & - \\
$\mathrm{A}^{2}$ & 0.48 & 1 & 0.48 & 18.62 & 0.0015 & - \\
$\mathrm{B}^{2}$ & 0.47 & 1 & 0.47 & 18.17 & 0.0017 & - \\
$\mathrm{C}^{2}$ & 0.30 & 1 & 0.30 & 11.60 & 0.0067 & - \\
$\mathrm{AB}$ & 5.25 & 1 & 5.25 & 204.96 & $<0.0001$ & - \\
$\mathrm{AC}$ & 0.039 & 1 & 0.039 & 1.53 & 0.2443 & - \\
$\mathrm{BC}$ & 0.11 & 1 & 0.11 & 4.13 & 0.0695 & - \\
Residual & 0.26 & 10 & 0.026 & - & - & - \\
Lack of fit & 0.21 & 5 & 0.043 & 4.93 & 0.0524 & Not significant \\
Pure error & 0.043 & 5 & $8.640 \mathrm{E}-003$ & - & - & - \\
Cor. Total & 25.38 & 19 & - & - & - & - \\
\hline
\end{tabular}

Table 5

Analysis of variance (ANOVA) surface quadratic model for exoglucanase (FPase)

\begin{tabular}{lcccccc}
\hline Source & Sum of squares & DF & Mean square & $F$ value & Prob $>$ F value & Remark \\
\hline Model & 24.50 & 9 & 2.72 & 74.56 & $<0.0001$ & Significant \\
$\mathrm{A}=\mathrm{pH}$ & 9.58 & 1 & 9.58 & 269.48 & $<0.0001$ & - \\
$\mathrm{B}=$ temperature & 7.90 & 1 & 7.90 & 216.44 & $<0.0001$ & - \\
$\mathrm{C}=\mathrm{NH}_{4} \mathrm{SO}_{4}$ & 0.28 & 1 & 0.28 & 7.55 & 0.0206 & - \\
$\mathrm{A}^{2}$ & 0.20 & 1 & 0.20 & 5.42 & 0.0422 & - \\
$\mathrm{B}^{2}$ & 0.83 & 1 & 0.83 & 22.63 & 0.0008 & - \\
$\mathrm{C}^{2}$ & 0.23 & 1 & 0.23 & 6.20 & 0.0320 & - \\
$\mathrm{AB}$ & 4.67 & 1 & 4.67 & 127.80 & 0.0001 & - \\
$\mathrm{AC}$ & 0.21 & 1 & 0.21 & 5.87 & 0.0358 & - \\
$\mathrm{BC}$ & 0.11 & 1 & 0.11 & 2.96 & 0.1160 & - \\
$\mathrm{Residual}$ & 0.37 & 10 & 0.037 & - & - & - \\
Lack of fit & 0.27 & 5 & 0.054 & 2.80 & 0.1414 & Not significant \\
Pure error & 0.096 & 5 & 0.019 & - & & - \\
Cor. Total & 24.87 & 19 & - & - & - & - \\
\hline
\end{tabular}

CMCase $=(19.07785)+(-0.51475 * \mathrm{~A})+(-0.58746 * \mathrm{~B})+(-0.16350 * \mathrm{C})+\left(-0.033600 \times \mathrm{A}^{2}\right)+\left(4.00000 \mathrm{E}-003 * \mathrm{~B}^{2}\right)+(-$ $\left.0.052500 * \mathrm{C}^{2}\right)+(0.017300 * \mathrm{AB})+(0.018750 * \mathrm{AC})+(4.62500 \mathrm{E}-003 * \mathrm{BC})$

FPase $=(20.92858)+(-0.91753 x A)+(-0.5693 x B)+(-0.34291 \times C)+\left(-0.024436 \times A^{2}\right)(-0.56937 x B)+(-0.34291 \times C)+$ $\left(-0.024436 \mathrm{~A}^{2}\right)+\left(3.43232 \mathrm{E}-003 \mathrm{xB}^{2}\right)+\left(-0.036932 \mathrm{CC}^{2}\right)+(0.021033 \mathrm{xAB})+(0.027750 \mathrm{xAC})+(4.62500 \mathrm{E}-003 \times \mathrm{BC})(3)$

The interaction between ammonium sulphate concentration and enzyme production showed a major effect. An increase in ammonium sulphate concentration enhanced enzyme production from 1 to $3 \%$, while further increments led to a decrease in enzyme production. The optimum enzyme production was found at $3 \%$ ammonium sulphate and $\mathrm{pH}$ 8.5. An excellent correlation was also observed between $\mathrm{pH}$ and temperature, as well as temperature and ammonium sulphate concentration.

\section{Validation of statistical experiments}

The accurate prediction and the evaluation of the model's fitness for each variable investigated require validation of the model by both graphical and numeric approaches. Based on the RSM-CCD results, the optimum conditions for enzyme production were 8.5 initial $\mathrm{pH}, 45^{\circ} \mathrm{C}$ temperature and $3 \%$ ammonium sulphate concentration, while incubation time was kept constant (8 days). The findings revealed an actual enzyme production of $4.26 \mathrm{IU} / \mathrm{mL}$ for both CMCase and FPase. 
These experiments were conducted based on the different predicted experiments for the three factors identified as $\mathrm{pH}$, temperature and $\mathrm{NH}_{4} \mathrm{SO}_{4}$ concentration, in order to validate the results previously obtained by CCD. A comparison between OFAT and RSM revealed increased enzyme activity of $0.74 \mathrm{IU} / \mathrm{mL}$ and $0.56 \mathrm{FPU} / \mathrm{mL}$ for CMCase and FPase, respectively, as compared to OFAT (Table 6). This indicated that RSM yields higher cellulase enzyme activity values, as compared to OFAT and other conventional methods of enzyme production. ${ }^{42}$
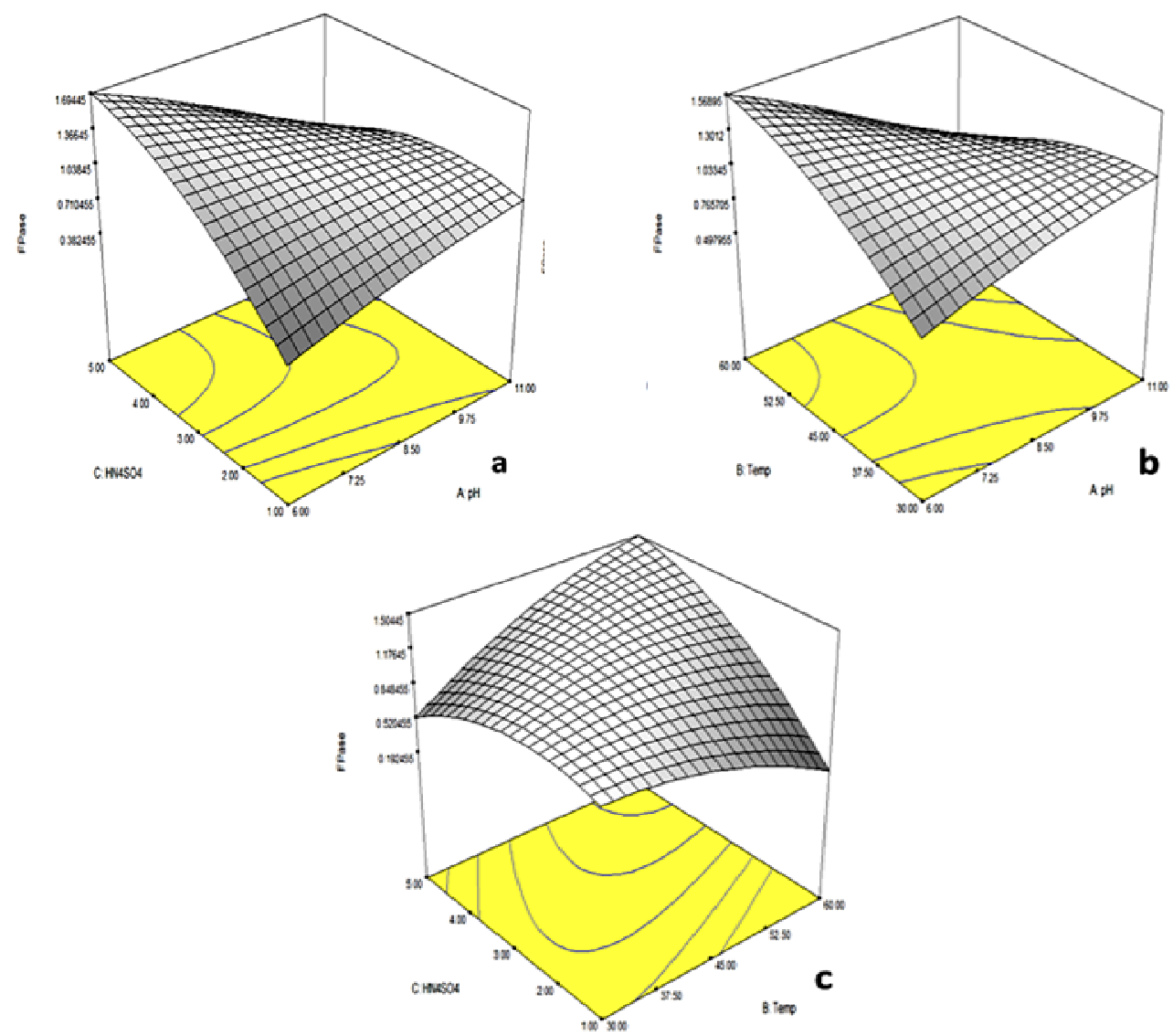

Figure 6: 3D response surface plots for the optimization of cellulase enzyme, showing the interactive effects of three different parameters

Table 6

Validation of optimum conditions and results obtained by OFAT and RSM for the production of CMCase and FPase

\begin{tabular}{lcccc}
\hline \multirow{2}{*}{ Factors } & \multicolumn{2}{c}{ CMCase $(\mathrm{IU} / \mathrm{mL})$} & \multicolumn{2}{c}{ FPase $(\mathrm{FPU} / \mathrm{mL})$} \\
\cline { 2 - 5 } & OFAT & RSM & OFAT & RSM \\
\hline $\mathrm{pH}$ & 6 & 8.5 & 6 & 8.5 \\
Temperature $\left({ }^{\circ} \mathrm{C}\right)$ & 30 & 45 & 30 & 45 \\
$\mathrm{NH}_{4} \mathrm{SO}_{4}(\%)$ & 3 & 3 & 3 & 3 \\
Enzyme activity & 3.52 & 4.26 & 3.70 & 4.26 \\
Enzyme increase & - & 0.74 & - & 0.56 \\
\hline
\end{tabular}

\section{Evaluation of endoglucanase enzyme deinking} potential

The results in Table 7 show the optical and mechanical properties (brightness, tensile strength, bursting strength and tearing strength) of the handsheets prepared from enzymatically treated pulp, with crude alkaline endoglucanase, and chemically deinked and control pulps. The 
brightness of $81.63 \%$ was recorded for the handsheet from enzymatically treated pulp, as compared to $81.51 \%$ and $79.63 \%$ for chemically treated and control pulps, respectively. Thus, an improvement in ISO brightness of $1.00 \%$ and $0.12 \%$ was obtained following the enzymatic treatment (Fig. 7a).

Table 7

Optical and mechanical properties of handsheets made from enzymatically and chemically deinked pulps, as well as from the control

\begin{tabular}{llcccc}
\hline S/No. & Test parameter & Unit & Control & Chemically deinked & WSSDBS2F1deinked \\
\hline 1 & Brightness & $\%$ & 79.63 & 81.51 & 81.63 \\
2 & Tensile strength & $\mathrm{N} / \mathrm{m}$ & 1070 & 953 & 1250 \\
3 & Bursting strength & $\mathrm{KPa}$ & 56 & 58 & 67 \\
4 & Tearing strength & $\mathrm{mN}$ & 285 & 279 & 352 \\
\hline
\end{tabular}

Previous studies have reported on the deinking of different types of waste papers using quite a number of fungal species, including Aspergillus oryzae MDU-4, Ganoderma lucidum MDU-7, Trichoderma citrinoviride MDU-1, Trichoderma harzyianum PPDDN10, Mucor hiemalis Aspergillus sp., Aspergillus terreus AN1 and Myceliophthora fergusii T41. ${ }^{9,12-15,43-47}$ However, in most of these works, the fungi were isolated at a $\mathrm{pH}$ within the acidic to neutral range. The mechanical properties of the obtained handsheets also showed improvements for the enzymatically treated pulp, compared to the control and the chemically treated one, as follows: tensile strength of $1250 \mathrm{~N} / \mathrm{m}$ (compared to 1070 and 953 $\mathrm{N} / \mathrm{m}$ ), burst strength of $67 \mathrm{KPa}$ (compared to 56 and $58 \mathrm{KPa}$ ), and tear index of $352 \mathrm{mN}$ (compared to 285 and $279 \mathrm{mN}$ ) (Figs. 7 and 8).

Scanning electron microscopy (SEM) and Fourier transform infrared spectroscopy (FTIRS) were conducted in order to confirm the influence of the enzyme on the structure of the pulps. It was observed that the enzymatic action leads to internal fibrillation, as well as some degree of surface fibrillation of the fibre.
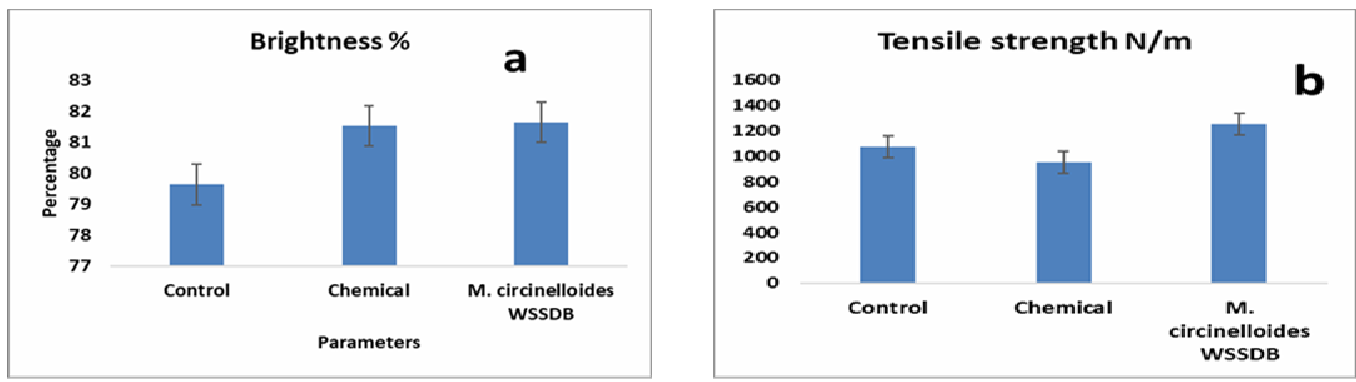

Figure 7: (a) Percentage brightness and (b) tensile strength of handsheets made from enzymatically deinked, chemically deinked and control pulps (error bars represent mean \pm standard deviation)
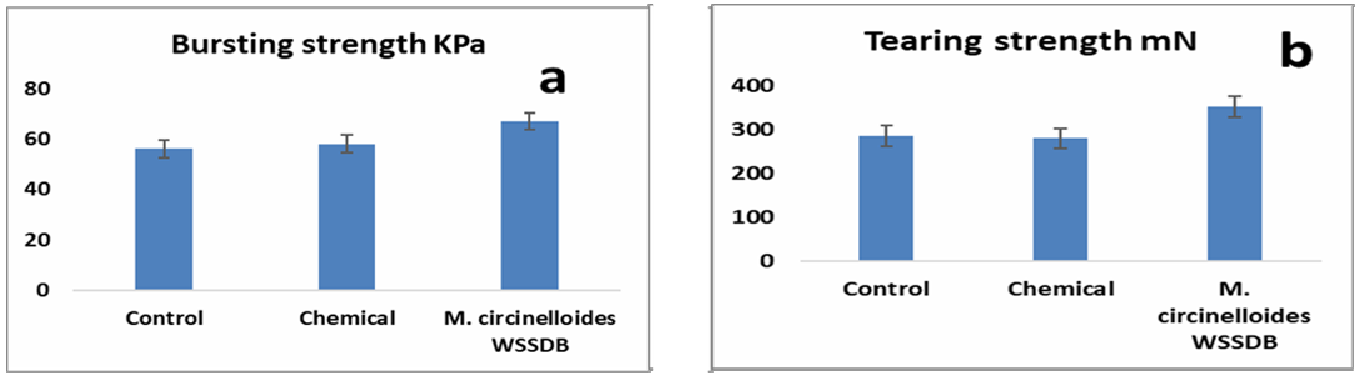

Figure 8: (a) Burst and (b) tearing strength of handsheets made from enzymatically deinked, chemically deinked and control pulps (error bars represent mean \pm standard deviation) 

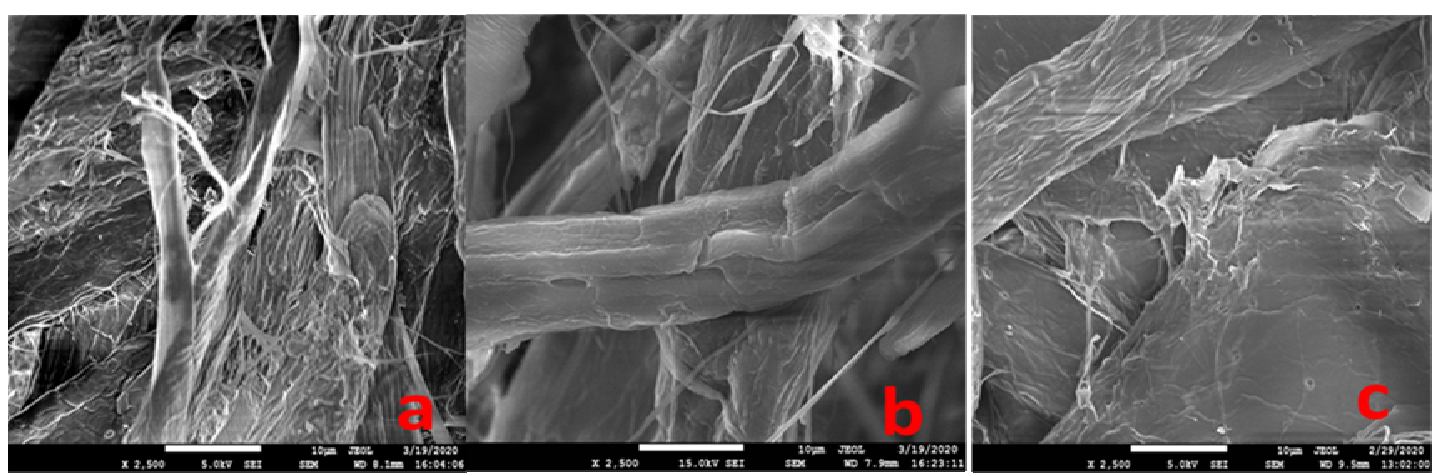

Figure 9: Scanning electron microscopy images of (a) CMCase treated, (b) chemically treated and (c) control untreated pulps at x500 magnification

This internal and surface fibrillation of the fiber due to the enzymatic treatment, which can be clearly seen on the SEM micrographs (Fig. 9), compared to chemically deinked and control untreated pulps, leads to increased strength. Attenuated total reflectance-Fourier transform infrared spectroscopy (ATR-FTIR) was carried out on the enzymatically deinked pulp, chemically deinked and control samples in order to examine the surface functional groups of the pulps. The FTIR spectra of the three pulp samples were recorded over a range of 4000-400 $\mathrm{cm}^{-1}$, using 25 scans per sample at a resolution of $4 \mathrm{~cm}^{-1}$. There was a clear peak assigned to the hydroxyl group ($\mathrm{OH}$ ) of cellulose between $3333 \mathrm{~cm}^{-1}$ to $3335 \mathrm{~cm}^{-1}$ present in the spectra of all the samples, but with different intensity - of $88.64 \%$ for enzymatically deinked pulp, as compared to $68.28 \%$ and $69.67 \%$ for the chemically treated and control pulps, respectively (Fig. 10). This increase in percentage intensity after enzymatic treatment is an indication of an increment in the cellulosic content of the pulp. Also, a decrease in intensity is observed for the enzymatically deinked pulp regarding a band between $3000 \mathrm{~cm}^{-1}$ and $2917 \mathrm{~cm}^{-}$ ${ }^{1}$, which was assigned to carbonyl stretching of the saturated ketone, which is an indication of degraded aliphatic side chains. These peaks were not observed for the control and chemically deinked pulps, thus confirming the effectiveness of the enzymatic deinking method.

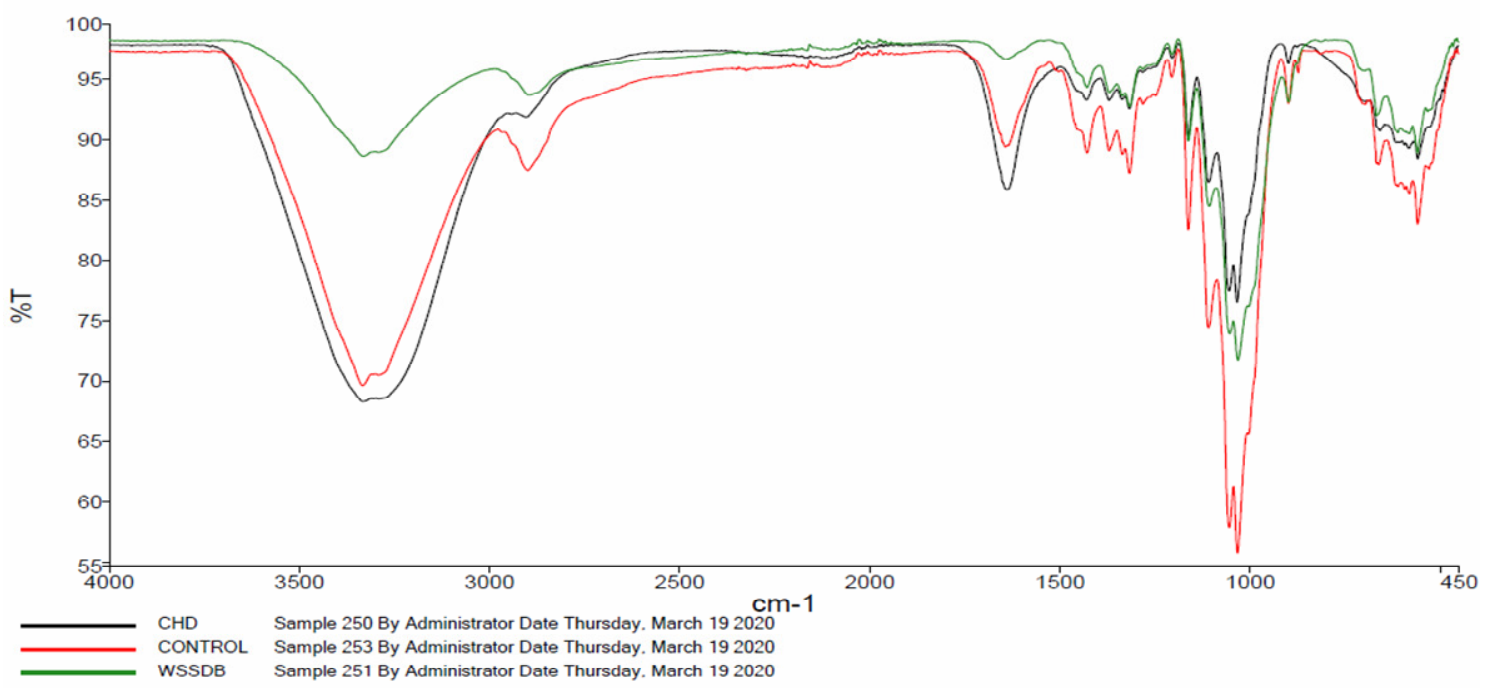

Figure 10: Changes in the structure of the enzymatically deinked pulp, compared to the chemically deinked and control pulp samples analyzed by FTIR spectroscopy (CHD = chemical deinking)

Saini $^{43}$ revealed significant changes in the chemical, as well as the surface structure, of prepared handsheets using SEM, TEM, FTIR and XRD analyses. They reported a similar decrease 
in intensity of the peak at $1270 \mathrm{~cm}^{-1}$ for the cellulase treated NP and ozone-treated PP, which confirmed the presence of degraded cellulose. Other researchers also reported decreases in peak intensity for enzyme-treated pulps, analyzed by ATR-FTIR spectroscopy, as compared to chemically treated or control pulps. ${ }^{48}$

\section{CONCLUSION}

In this research, response surface methodology (RSM) was found to be an efficient tool for the optimization of cellulase enzyme production from alkaliphilic $M$. circinelloides WSSDBS2F1, as compared to other methods. The optimized alkaline endoglucanase was found to have good deinking potential, when compared to the conventional chemical deinking method. The enzymatic treatment applied in this study has led to an improvement in both optical and mechanical properties, as compared to chemically treated and control pulps. These improvements in brightness and mechanical properties of the enzyme-treated pulp were related to SEM and ATR-FTIR observations of the pulps.

ACKNOWLEDGEMENT: The authors acknowledge the support from the Tertiary Education Trust Fund (TETFund), Abuja Nigeria, Jigawa State Polytechnic Dutse, Nigeria, and Lovely Professional University Punjab, India.

\section{REFERENCES}

1 V. N. Kumar, S. R. Kanthimathinathan, M. E. Rani, G. Rathinasamy and N. D. Kannan, Cellulose, 25, 4179 (2018), https://doi.org/10.1007/s10570-0181834-Z

2 M. A. M. Abo-State, M. Fadel, E. M. Abdellah and M. F. Ghaly, Am. J. Agric. Environ. Sci., 13, 1568 (2013), https://doi.org/10.5829/idosi.aejaes.2013.13.11.11262

3 V. N. Kalpana and V. D. Rajeswari, Asian J. Biochem., 1, 8 (2015), https://doi.org/10.3923/ajb.2015

4 D. N. Adhyaru, N. S. Bhatt, H. A. Modi and J. Divecha, Biocatal. Agric. Biotechnol., 12, 220 (2017), https://doi.org/10.1016/j.bcab.2017.10.010

F. Wang, X. Zhang and G. Zhang, Cellulose, 1, 11 (2018), https://doi.org/10.1007/s10570-018-1778-3

6 E. M. Nyakeri, R. Mwirichia and H. Boga, J. Microbiol. Exp., $\quad$ 6, 2 (2018), https://doi.org/10.15406/jmen.2018.06.00189

7 K. Vega, G. K. Villena, V. H. Sarmiento, Y. Ludeña, N. Vera et al., Biotechnol. Res. Int., 1, 7 (2012), https://doi.org/10.1155/2012/934325

8 Y. K. Kim, S. C. Lee, Y. Y. Cho, H. J. Oh and Y. H. Ko, ISRN Microbiol., 1, 9 (2012), https://doi.org/10.5402/2012/650563
9 P. Pathak, N. K. Bhardwaj and A. K. Singh, BioResources, $\quad 6, \quad 447 \quad$ (2011), https://bioresources.cnr.ncsu.edu/wpcontent/uploads/2016/06/BioRes_06_1_0447_Pathak_ BS_Opt_Chem_Enzym_Deinking_Photocopier_Paper 1117.pdf

10 A. Saxena and P. S. Chauhan, Crit. Rev. Biotechnol., $\quad 8551, \quad 7$ (2016), https://doi.org/10.1080/07388551.2016.1207594

11 T. K. Kirk, T. W. Jeffries, O. Gifford and P. Drive, "Roles for Microbial Enzymes in Pulp and Paper Processing", Washington DC, American Chemical Society, 1996

12 D. E. Tsatsis, D. K. Papachristos, K. A. Valta and A. G. Vlyssides, J. Environ. Chem. Eng., 5, 2 (2017), https://doi.org/10.1016/j.jece.2017.03.007

${ }_{13} \mathrm{X}$. Zhang, S. Renaud and M. Paice, Enzyme Microb. Technol., 43, 103 (2008), https://doi.org/10.1016/j.enzmictec.2007.11.005

14 M. Roushdy, J. Adv. Biol. Biotechnol., 2, 3 (2015), https://doi.org/10.9734/JABB/2015/15378

15 P. Pathak, N. K. Bhardwaj and A. K. Singh, Appl. Biochem. Biotechnol., 27, 2 (2014), https://doi.org/10.1007/s12010-014-0758-9

16 S. Rohit, N. Asiya, B. S. Chandha and H. S. Saini, BioResources, 3, $234 \quad$ (2008), https://bioresources.cnr.ncsu.edu/BioRes_03/BioRes_0 3_1_0234_Soni_NCS_FungalCellulases_Deinking.pdf 17 P. Prasad, T. Singh and S. Bedi, J. King Saud Univ. Sci.

(2013),

https://doi.org/10.1016/j.jksus.2013.03.003

${ }_{18}$ H. Muhammad, N. Iqbal, I. Ahmed, M. A. Zia and M. Irfan, Adv. Biosci. Biotechnol., 2, 6 (2011), https://doi.org/10.4236/abb.2011.23024

19 S. Dutta, M. Tarafder and B. Datta, Biocatal. Agric.

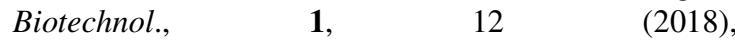
https://doi.org/10.1016/j.bcab.2018.03.011

${ }^{20}$ P. K. Kumar, G. Hermanth, P. S. Niharika and S. K. Kolli, Int. J. Adv. Pharm., Biol. Chem., 4, 484 (2015)

21 R. Gaur and S. Tiwari, BMC Biotechnol., 15, 1 (2015), https://doi.org/10.1186/s12896-015-0129-9

22 L. Ram, K. Kaur and S. Sharma, Int. J. Pharm. Sci. Invent., 3, 12 (2014)

23 R. Rajendran, R. Radhai, K. S. Sundaram and V. Rajalakshmi, Int. J. Environ. Sci., 5, 4 (2015), https://doi.org/10.6088/ijes.2014050100069

24 W. Qiao, J. Tao, Y. Luo and T. Tang, R. Soc. Open $\begin{array}{llll}\text { Sci., } & \mathbf{5}, & 180551 & \text { (2018), }\end{array}$ http://dx.doi.org/10.1098/rsos.180551

25 E. Abatenh, B. Gizaw, Z. Tsegaye and M. Wassie, J. Environ. Microbiol., 1, 2 (2017), https://doi.org/10.17352/ojeb.000007

26 E. E. Asira, Acad. J. Interdiscip. Stud., 13, 2 (2013), https://doi.org/10.5901/ajis.2013.v2n13p125

27 B. S. Saha, Process Biochem., 39, 1871 (2004), https://doi.org/10.1016/j.procbio.2003.09.013

28 J. Sadaf, K. Nazia, J. Saman, S. Muhammad, S. S. Saleem et al., Pak. J. Bot., 37, 3 (2005) 
29 C. Ravindran, T. Naveenan and G. R. Varatharajan, Bot. Mar., $\quad$ 53, 3 (2010), https://doi.org/10.1515/BOT.2010.026

30 A. Sasi, M. Ravikumar and S. Manthirikani, African J. Microbiol. Res., 6, 20 (2012), https://doi.org/10.5897/AJMR11.074

31 N. H. Bhavsar, B. V. Raol, S. S. Amin and G. G. Raol, Int. J. Curr. Appl. Sci., 4, 30 (2015), https://www.ijcmas.com/vol-4-

3/N.H.Bhavsar,\%20et\%20al.pdf

32 A. Vyas, D. Vyas and K. M. Vyas, J. Sci. Ind. Res.,

64, 281

$(2005)$

http://nopr.niscair.res.in/bitstream/123456789/5139/1/J

SIR\%2064\%284\%29\%20281-286.pdf

33 G. Ramanathan, S. Banupriya and D. Abirami, $J$. Sci. Ind. Res. (India), 69, 454 (2010), http://nopr.niscair.res.in/handle/123456789/9685

34 A. A. El-hadi, S. A. El-nour, A. Hammad and Z. Kamel, J. Radiat. Res. Appl. Sci., 7, 23 (2014), https://doi.org/10.1016/j.jrras.2013.11.003

35 V. B. Borugadda and V. V. Goud, Energ. Sci. Eng., 3, 4 (2015), https://doi.org/10.1002/ese3.77

36 I. Yusuf, S. Aqlima and L. Y. Phang, J. Environ. Manag., $\quad \mathbf{1 8 3}, \quad 182 \quad$ (2016), https://doi.org/10.1016/j.jenvman.2016.08.059

37 S. Sharma, A. Malik and S. Satya, J. Hazard. Mater., $\quad \mathbf{1 6 4}, \quad 1198 \quad$ (2009), https://doi.org/10.1016/j.jhazmat.2008.09.030

38 S. A. Hassanzadeh-Tabrizi and E. Taheri-Nassaj, $J$. Sol-Gel Sci. Technol., 57, 2 (2011), https://doi.org/10.1007/s10971-010-2344-0
39 M. Manogaran, M. Y. Shukor, N. A. Yasid, K. A. Khalil and S. A. Ahmad, 3 Biotech., 8, 2 (2018), https://doi.org/10.1007/s13205-018-1123-4

40 S. Ibrahim, M. Y. Shukor, K. A. Khalil, M. I. E. Helmi, M. A. Syed et al., J. Environ. Biol., 36, 1215 (2015), https://doi.org/10.4314/bajopas.v8i2.24

41 C. J. B. De-Lima, L. F. Coelho and J. Contiero, Food Technol. Biotechnol., 48, 175 (2010), https://www.ftb.com.hr/images/pdfarticles/2010/AprilJune/48_175.pdf

42 B. T. Hao and P. V. Hung, Int. Food Res. J., 20, 3269 (2013)

${ }^{43}$ S. Saini, P. Chutani, P. Kumar and K. K. Sharma, Renew. Energ., 146, 2362 (2020), https://doi.org/10.1016/j.renene.2019.08.087

44 R. Soni, A. Nazir and B. S. Chadha, Ind. Crop. Prod., $\quad 31, \quad 277 \quad$ (2010), https://doi.org/10.1016/j.indcrop.2009.11.007

45 D. Ibarra, M. C. Monte, A. Blanco, A. T. Martínez and M. J. Martínez, J. Ind. Microbiol. Biotechnol., 39, 1 (2012), https://doi.org/10.1007/s10295-011-0991-y

46 A. Singh, R. D. Yadav, A. Kaur and R. Mahajan, Bioresour. Technol., 120, 322 (2012), https://doi.org/10.1016/j.biortech.2012.06.050

47 C. K. Lee, D. Ibrahim and I. C. Omar, Process Biochem., $\quad 48, \quad 2013)$, https://doi.org/10.1016/j.procbio.2012.12.015

48 D. I. Desai and B. D. Iyer, Biocatal. Agric. $\begin{array}{llll}\text { Biotechnol., } & 5, & 78 & \text { (2016), }\end{array}$ https://doi.org/10.1016/j.bcab.2015.11.001 